\title{
ЧАСОВІ ХАРАКТЕРИСТИКИ ТЕХНІКИ СТРИБКА У ВИСОТУ ВИСОКОКВАЛІФІКОВАНИХ СТРИБУНОК
}

\author{
Конестяпін В. Г., Канд. пед. наук, дочент Львівський державний університет фізичної \\ культури імені Івана Боберського, Украйна, Львів \\ Павлось О. О., Канд. наук з фіз. вих. і спорту, доцент, Львівський державний університет \\ фізичної культури імені Івана Боберського, Україна, Львів \\ Ханікянц О. В., Канд. наук з фіз. вих. і спорту, доцент, Львівський державний університет \\ фізичної культури імені Івана Боберського, Украӥна, Львів \\ Свищ Я. С., Канд. наук з фіз. вих. і спорту, доцент, Львівський державний університет \\ фізичної культури імені Івана Боберського, Украйна, Львів \\ Павлось Р. М., Старший викладач, Національний університет «Львівська Політехніка», \\ Україна, Львів
}

DOI: https://doi.org/10.31435/rsglobal_wos/30042020/7048

\section{ARTICLE INFO}

Received: 20 February 2020

Accepted: 19 April 2020

Published: 30 April 2020

\section{KEYWORDS}

high jump,

highly skilled jumpers,

technique,

time characteristics

\begin{abstract}
The increasing performance in women's height jumping among women is of interest to the study of time characteristics of technique. The aim was to supplement the data on the time characteristics of the technique of jumping into the height of highly skilled jumpers during participation in responsible competitions. Based on a report by the IAAF scientific group, made after the 2017 World Championship in London, the time characteristics of high jump technique for the finalists were determined. The relationship between the result of a high jump and the time characteristics of the technique of the jumping a world-class athlete has been investigated. Comparison of time characteristics of the technique of jumping of the finalists of the 2017 World Championship with the time characteristics of the technique of jumping off the world record holder among the juniors Yaroslava Mahuchikh. It is recommended to use as a model the characteristics of highly skilled high jumpers: average rate of the last three running steps $(4.1 \pm 0.3 \mathrm{step} \cdot \mathrm{s}-1)$ and repulsion duration $(0.16 \pm 0.01 \mathrm{~s})$.
\end{abstract}

Citation: Конестяпін В. Г., Павлось О. О., Ханікянц О. В., Свищ Я. С., Павлось Р. М. (2020) Chasovi Kharakterystyky Tekhniky Strybka u Vysotu Vysokokvalifikovanykh Strybunok. International Academy Journal Web of Scholar. 4(46). doi: 10.31435/rsglobal_wos/30042020/7048

Copyright: (C 2020 Конестяпін В. Г., Павлось О. О., Ханікянц О. В., Свищ Я. С., Павлось Р. М. Тhis is an open-access article distributed under the terms of the Creative Commons Attribution License (CC BY). The use, distribution or reproduction in other forums is permitted, provided the original author(s) or licensor are credited and that the original publication in this journal is cited, in accordance with accepted academic practice. No use, distribution or reproduction is permitted which does not comply with these terms.

Вступ. На сучасному етапі розвитку легкої атлетики спостерігається високий рівень результатів, зокрема у стрибках у висоту серед жінок. Зважаючи на збільшення кількості висококваліфікованих стрибунок у висоту в різних країнах світу, які намагаються підкорити рекордні висоти, виникає необхідність 3'ясування часових характеристик техніки стрибка у висоту висококваліфікованих стрибунок під час виступів на змаганнях високого рівня.

Протягом останніх років дослідженню часових характеристик техніки стрибка у висоту висококваліфікованих стрибунів приділялося достатньо уваги. Проведено дослідження зі стрибунами у висоту різної кваліфікації в умовах навчально-тренувальних занять та підвідних змагань $[2,8,12]$. Але думки спеціалістів щодо оцінки часових характеристик техніки стрибка різні. Так наприклад, окремі дослідники вважають що збільшення темпу останнього кроку розбігу призводить до різкого зменшення тривалості відштовхування, тим самим ламаючи його структуру [5, 6]. Найбільш оптимальним показником тривалості відштовхування вважається 0,18 - 0,22 с [9, 11]. Результати інших досліджень показали - зі зростанням спортивної 
кваліфікації стрибунів у висоту тривалість фази відштовхування зменшується і цей показник коливається в межах $0,15-0,18$ с. $[1,3,7]$. У стрибунів у висоту темп останнього кроку розбігу дорівнює $4,5-5,5$ крок' $\mathrm{c}^{-1}$, при чому на останніх трьох кроках розбігу виражено зростає на 1,0 $-1,5$ крок $\cdot \mathrm{c}^{-1}[4,6,7]$.

Отже, на сьогодні, залишається актуальним уточнення кількісних значень часових характеристик техніки стрибка у висоту висококваліфікованих стрибунок під час участі у відповідальних змаганнях.

Метою роботи $є$ доповнення даних, щодо часових характеристик техніки стрибка у висоту висококваліфікованих стрибунок під час участі у відповідальних змаганнях. Для вирішення мети роботи були поставлені наступні завдання: на підставі даних звіту IААФ «Biomechanical report for the high jump women's» визначити часові характеристики техніки стрибка у висоту фіналісток Чемпіонату світу 2017 року; дослідити взаємозв'язки між результатом стрибка у висоту та часовими характеристиками техніки висококваліфікованих стрибунок; порівняти часові характеристики техніки стрибка у висоту фіналісток Чемпіонату світу 2017 року з часовими характеристиками техніки стрибка у висоту рекордсменки світу серед юніорів Ярослави Магучіх.

Методика дослідження. Провівши аналіз Звіту ІААФ, таблиця 8, рисунки 20 i 21 [10] було визначено та розраховано такі часові характеристики техніки стрибка у висоту фіналісток Чемпіонату світу 2017 року: середній темп трьох останніх кроків розбігу $\left(\mathbf{T}_{3}\right.$, крок. $\left.\mathrm{c}^{-1}\right)$, темп останнього кроку розбігу $\left(\mathbf{T}_{\mathbf{0}}\right.$, крок $\left.\mathrm{c}^{-1}\right)$, середня тривалість опори трьох останніх кроків розбігу $\left(\mathbf{t}_{3}, \mathbf{c}\right)$, тривалість опори останнього кроку розбігу $\left(\mathbf{t}_{\mathbf{0}}, \mathbf{c}\right)$, середня тривалість польоту трьох останніх кроків розбігу $\left(\mathbf{t}_{\mathbf{m} 3}, \mathbf{c}\right)$, тривалість польоту останнього кроку розбігу $\left(\mathbf{t}_{\mathbf{n}}, \mathbf{c}\right)$, тривалість відштовхування $\left(\mathbf{t}_{\mathbf{B}}, \mathbf{c}\right)$, коефіцієнт активності трьох останніх кроків розбігу $\left(\mathbf{A}_{\mathbf{3}}-\right.$ відношення тривалості польотних періодів до опорних, відносні одиниці), коефіцієнт активності останнього

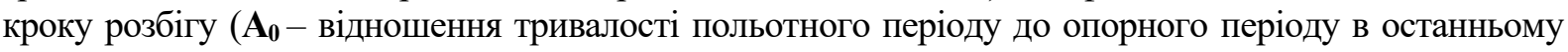
кроці розбігу, відносні одиниці). Розраховувалися середні значення $(\bar{X}, \pm \sigma)$ та варіативність (V\%) часових характеристик, визначались кореляційні взаємозв'язки між кращим результатом стрибка у висоту показаним на Чемпіонаті світу 2017 року та часовими характеристиками техніки стрибунок.

Визначення часових характеристик техніки стрибка у висоту Ярослави Магучіх проводилося на підставі аналізу вдалої спроби на висоті 2,01 м, показаної на Міжнародних змаганнях зі стрибків у висоту "Меморіал Олексія Дем'янюка" 18 січня 2020 року у місті Львові. Педагогічне спостереження проводилося за допомогою відеозйомки (відеокамера Sony DCR-XR 150Е). Відео проаналізовано з використанням спеціалізованої програми - Tracker -4.87.

Результати. Середній результат стрибка у висоту кращих спроб фіналісток Чемпіонату

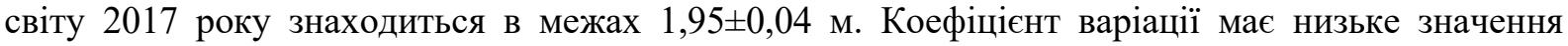
$(2,1 \%)$, що свідчить про однорідність групи (n=12) висококваліфікованих стрибунок (табл. 1).

Таблиця 1. Часові характеристики техніки стрибка у висоту фіналісток Чемпіонату світу 2017 року

\begin{tabular}{|c|c|c|c|c|c|c|c|c|c|c|}
\hline $\begin{array}{l}\text { Прізвище, ім'я } \\
\text { (країна) }\end{array}$ & $\begin{array}{l}\text { Ре3-т } \\
(\mathrm{M})\end{array}$ & $\mathrm{T}_{3}$ & $\mathrm{~T}_{\mathrm{o}}$ & $\mathrm{t}_{3}$ & $t_{0}$ & $\mathrm{t}_{\mathrm{m} 3}$ & $\mathrm{t}_{\text {по }}$ & $t_{B}$ & $\mathrm{~A}_{3}$ & $\mathrm{~A}_{\mathrm{o}}$ \\
\hline 1 & 2 & 3 & 4 & 5 & 6 & 7 & 8 & 9 & 10 & 11 \\
\hline Ласіцкене М. (ANA) & 2,03 & 3,9 & 4,8 & 0,15 & 0,15 & 0,11 & 0,06 & 0,17 & 0,7 & 0,4 \\
\hline Левченко Ю. (UKR) & 2,01 & 3,6 & 4,0 & 0,16 & 0,16 & 0,12 & 0,09 & 0,16 & 0,8 & 0,6 \\
\hline Ліквікно К. (POL) & 1,99 & 3,9 & 4,8 & 0,14 & 0,16 & 0,12 & 0,05 & 0,16 & 0,9 & 0,3 \\
\hline $\begin{array}{l}\text { Джангфлієш М.-Л. } \\
\text { (GER) }\end{array}$ & 1,95 & 4,2 & 4,8 & 0,14 & 0,14 & 0,1 & 0,07 & 0,14 & 0,7 & 0,5 \\
\hline $\begin{array}{l}\text { Джонсон-Томпсон } \\
\text { K. (GBR) }\end{array}$ & 1,95 & 4,0 & 5,6 & 0,14 & 0,13 & 0,11 & 0,05 & 0,16 & 0,8 & 0,4 \\
\hline Лайк M. (GBR) & 1,95 & 3,6 & 4,0 & 0,16 & 0,18 & 0,12 & 0,07 & 0,15 & 0,8 & 0,4 \\
\hline Демірьова М. (BUL) & 1,92 & 4,4 & 5,3 & 0,12 & 0,13 & 0,11 & 0,06 & 0,17 & 0,9 & 0,5 \\
\hline Палсуте А. (LTU) & 1,92 & 3,7 & 4,2 & 0,16 & 0,17 & 0,11 & 0,07 & 0,17 & 0,7 & 0,4 \\
\hline Макферсен I (USA) & 1,92 & 4,5 & 4,8 & 0,13 & 0,15 & 0,09 & 0,06 & 0,15 & 0,7 & 0,4 \\
\hline Каннінгхам В. (USA) & 1,92 & 4,5 & 5,3 & 0,13 & 0,13 & 0,09 & 0,06 & 0,17 & 0,7 & 0,5 \\
\hline
\end{tabular}


Продовження таблиці 1.

\begin{tabular}{|l|c|c|c|c|c|c|c|c|c|c|}
\hline \multicolumn{1}{|c|}{1} & 2 & 3 & 4 & 5 & 6 & 7 & 8 & 9 & 10 & 11 \\
\hline Хруба М. (CZE) & 1,92 & 4,0 & 4,2 & 0,18 & 0,20 & 0,07 & 0,04 & 0,19 & 0,4 & 0,2 \\
\hline Бетіа P. (ESP) & 1,88 & 4,5 & 5,0 & 0,15 & 0,14 & 0,07 & 0,06 & 0,15 & 0,5 & 0,4 \\
\hline $\bar{X}$ & 1,95 & 4,1 & 4,7 & 0,15 & 0,15 & 0,10 & 0,06 & 0,16 & 0,7 & 0,4 \\
\hline$\pm \sigma$ & 0,04 & 0,3 & 0,5 & 0,02 & 0,02 & 0,02 & 0,01 & 0,01 & 0,1 & 0,1 \\
\hline $\mathbf{V \%}$ & 2,1 & 7,3 & 10,6 & 13,3 & 13,3 & 20,1 & 16,7 & 6,3 & 14,3 & 25,0 \\
\hline $\mathbf{r}$ & - & $-0,58$ & 0,71 & $-0,77$ & 0,85 & $-0,06$ & 0,46 & $-0,45$ & $-0,29$ & 0,46 \\
\hline
\end{tabular}

Примітка: $\mathrm{r}_{10 ; 0,95}=0,58$

Аналізуючи часові характеристики техніки фіналісток Чемпіонату світу 2017 року було встановлено, що низьке значення коефіцієнта варіації (V\% < 10\%) спостерігається у наступних характеристиках: середній темп трьох останніх кроків розбігу та тривалість відштовхування. Низьке значення варіативності свідчить про те, що за даними характеристиками група $є$ дуже щільною, тому їх можна використовувати як модельні показники висококваліфікованих стрибунок у висоту.

Середнє значення коефіцієнту варіації (V\% 10 - 20\%) спостерігається у п'яти часових характеристиках техніки стрибка - темпі останнього кроку розбігу, середній тривалості опори трьох останніх кроків розбігу, тривалості опори останнього кроку розбігу, тривалості польоту останнього кроку розбігу, коефіцієнті активності трьох останніх кроків розбігу.

Висока варіативність $(\mathrm{V} \%>20 \%)$ часових характеристик техніки стрибка у висоту спостерігається у середній тривалості польоту трьох останніх кроків розбігу та коефіцієнті активності останнього кроку розбігу. Такі значення варіативності даних характеристик свідчать про те, що висококваліфіковані стрибунки використовують різні варіанти техніки поєднання розбігу з відштовхуванням.

Кореляційний аналіз між результатами стрибків у висоту фіналісток Чемпіонату світу 2017 року та часовими характеристиками техніки свідчить про таке:

- достовірний $(\mathrm{p} \leq 0,05)$ взаємозв'язок зворотного характеру спостерігається між результатом стрибка у висоту та такими характеристиками як середній темп трьох останніх кроків розбігу $\left(\mathbf{T}_{\mathbf{3}}\right)$ i середня тривалість опори трьох останніх кроків розбігу $\left(\mathbf{t}_{3}\right)$;

- достовірний $(\mathrm{p} \leq 0,05)$ взаємозв'язок прямого характеру спостерігається між результатом стрибка у висоту і такими характеристиками як темп останнього кроку розбігу $\left(\mathbf{T}_{\mathbf{0}}\right)$ та тривалість опори останнього кроку розбігу $\left(\mathbf{t}_{\mathbf{0}}\right)$;

- відсутність достовірного взаємозв'язку $(\mathrm{p}>0,05)$ спостерігається між результатом стрибка у висоту і такими характеристиками як середня тривалість польоту трьох останніх кроків розбігу $\left(\mathbf{t}_{\mathbf{m}}\right)$, тривалість польоту останнього кроку розбігу $\left(\mathbf{t}_{\text {по }}\right)$, тривалість відштовхування $\left(\mathbf{t}_{\mathbf{B}}\right)$, коефіцієнт активності трьох останніх кроків $\left(\mathbf{A}_{\mathbf{3}}\right)$ та коефіцієнт активності останнього кроку розбігу $\left(\mathbf{A}_{\mathbf{0}}\right)$.

Часові характеристиками техніки виконання стрибка у висоту рекордсменки світу серед юніорок Я. Магучіх наведено у таблиці 2.

Таблиця 2. Часові характеристики техніки стрибка у висоту Я. Магучіх (UKR)

\begin{tabular}{|c|c|c|c|c|c|c|c|c|c|}
\hline Результат (м) & $\mathbf{T}_{\mathbf{3}}$ & $\mathbf{T}_{\mathbf{0}}$ & $\mathbf{t}_{\mathbf{3}}$ & $\mathbf{t}_{\mathbf{0}}$ & $\mathbf{t}_{\mathbf{n} 3}$ & $\mathbf{t}_{\mathbf{n}}$ & $\mathbf{t}_{\mathbf{B}}$ & $\mathbf{A}_{\mathbf{3}}$ & $\mathbf{A}_{\mathbf{0}}$ \\
\hline 2,01 & 4,0 & 5,0 & 0,12 & 0,12 & 0,13 & 0,08 & 0,16 & 0,9 & 0,7 \\
\hline
\end{tabular}

Порівняння часових характеристик техніки стрибка у висоту фіналісток Чемпіонату світу 2017 року (табл. 1) із часовими характеристиками техніки стрибка у висоту рекордсменки світу серед юніорів Ярослави Магучіх (табл. 2) свідчить, що:

- характеристики темпу кроків розбігу $\left(\mathbf{T}_{3}, \mathbf{T}_{\mathbf{0}}\right)$ та тривалість відштовхування $\left(\mathbf{t}_{\mathbf{B}}\right)$ Я. Магучіх знаходяться в межах середніх значень групи фіналісток;

- характеристики тривалості опорних та польотних періодів останніх кроків розбігу $\left(\mathbf{t}_{3}\right.$, $\left.\mathbf{t}_{\mathbf{0}}, \mathbf{t}_{\mathbf{n}}, \mathbf{t}_{\mathbf{n o}}\right)$ Я. Магучіх відрізняються від середніх значень групи фіналісток менш тривалими опорними та більш тривалими польотними періодами; 
- коефіцієнти активності останніх кроків розбігу у Я. Магучіх $\left(\mathbf{A}_{3}=0,9\right.$ від. од. та $\mathbf{A}_{\mathbf{0}}=$ 0,7 від. од.) відрізняються від середніх значень коефіцієнтів активності останніх кроків розбігу групи фіналісток чемпіонату ( $\mathbf{A}_{\mathbf{3}}=0,7 \pm 0,1$ від. од. та $\mathbf{A}_{\mathbf{0}}=0,4 \pm 0,1$ від. од.). Це свідчить про те, що Я. Магучіх більшою мірою зберігає природню структуру бігу до самого відштовхування.

Порівняння абсолютних значень індивідуальних часових характеристик техніки стрибка Я. Магучіх та фіналісток Чемпіонату світу 2017 року показало, що:

- середній темп трьох останніх кроків розбігу Я. Магучіх $\left(4,0\right.$ крок· $\left.\mathrm{c}^{-1}\right)$ має ідентичне значення лише з К. Джонсон-Томпсон;

- темп останнього кроку розбігу $\left(5,0\right.$ крок $\left.\cdot \mathrm{c}^{-1}\right)$ співпадає лише з показником Р. Бетіа;

- середня тривалість опори трьох останніх кроків розбігу $(0,12$ с) ідентична лише 3 М. Демірьовою;

- тривалість відштовхування (0,16 с) співпадає 3 показниками таких стрибунок як Ю. Левченко, К. Ліквікно та К. Джонсон-Томпсон;

- показник коефіцієнту активності трьох останніх кроків розбігу $(0,9$ від. од.) крім Я. Магучіх мають ще дві стрибунки - К. Ліквінко та М. Демірьова;

- не співпадають значення часових характеристик тривалості опори останнього кроку розбігу $(0,12 \mathrm{c})$, середньої тривалості польоту трьох останніх кроків розбігу $(0,13 \mathrm{c})$, тривалості польоту останнього кроку розбігу $(0,08 \mathrm{c})$, коефіцієнту активності останнього кроку розбігу $(0,7$ від. од.) у Я. Магучіх та жодної з фіналісток Чемпіонату світу 2017 року.

Не зафіксовано жодного співпадіння абсолютних значень часових характеристик техніки стрибка Я. Магучіх із шістьма фіналістками, такими як: М. Ласіцкене, М.Л. Джангфлієш, М. Лайк, А. Палсуте, І. Макферсен та М. Хруба, що у свою чергу підкреслює індивідуальність техніки стрибка у висоту висококваліфікованих спортсменок.

Висновки. Визначено індивідуальні та середні значення дев'яти часових характеристик техніки стрибка у висоту фіналісток Чемпіонату світу 2017 року. У двох часових характеристиках техніки спостерігається низька варіативність, середнє значення варіативності спостерігається у п'яти часових характеристиках техніки стрибка та висока варіативність спостерігається у двох часових характеристиках техніки.

Досліджено кореляційні взаємозв'язки між результатом стрибка у висоту та часовими характеристиками техніки у висококваліфікованих стрибунок. Спостерігається достовірний $(\mathrm{p} \leq 0,05)$ взаємозв'язок зворотного характеру між результатом стрибка у висоту та середнім темпом трьох останніх кроків розбігу і середньою тривалістю опори трьох останніх кроків розбігу, також спостерігається достовірний $(\mathrm{p} \leq 0,05)$ взаємозв'язок прямого характеру між результатом стрибка у висоту та темпом останнього кроку розбігу і тривалістю опори останнього кроку розбігу.

Порівняння часових характеристик техніки стрибка у висоту фіналісток Чемпіонату світу 2017 року із часовими характеристиками техніки стрибка у висоту рекордсменки світу серед юніорів Ярослави Магучіх виявило між ними лише часткове співпадіння, що підкреслює індивідуальність техніки стрибка кожної стрибунки.

\section{ЛІТЕРАТУРА}

1. Бобровник В. И. Совершенствование технического мастерства спортсменов высокой квалификации в легкоатлетических соревновательных прыжках: монография / В. И. Бобровник. - К.: Наук. світ, 2005. - 322 c.

2. Динаміка та варіативність часових характеристик техніки стрибка у висоту у спортсменів високої кваліфікації / Володимир Конестяпін, Олена Ханікянц, Станіслав Онищук, Олександр Нартов, Віктор Шаповал // Молода спортивна наука України : зб. наук. пр. з галузі фіз. виховання, спорту $\mathrm{i}$ здоров'я людини / за заг. ред. Свгена Приступи. - Л., 2012. - Вип. 16, т. 1. - С. 113-117.

3. Козлова О. К. Сучасний аналіз техніки стрибка у висоту з розгону / О. К. Козлова // Теорія i методика фіз. виховання і спорту. - 2000. - № 1. - С. 13-17.

4. Легкая атлетика: ученик / [Аврутин С.Ю., Артюшенко А.Ф., Беца Н.Н. и др.; под. общ. ред. В. И. Бобровника, С. П. Совенка, А. В. Колота]. - К.: Логос, 2017. - С. 482-499.

5. Совершенствование технического мастерства спортсменов (Педагогические проблемы у правления) / Под общ. ред. Дьячкова В. М. - М. : Физкультура и спорт, 1972. - С. 87-100.

6. Стрижак А. Критерии технического майстерства прыгунов в высоту / Стрижак А. // Легкая атлетика. Москва., 2017. - № 3-4. С. 8-9. 
7. Ханікянц О. Ритмо-темпові характеристики розбігу провідних стрибунів у висоту світу / Олена Ханікянц, Володимир Конестяпін // Молода спортивна наука України : зб. наук. пр. $з$ галузі фіз. культури та спорту. - Л., 2009. - Вип. 13, т. 1. - С. 300-305.

8. Linthorne N. P. Take-off technique in the high jump / N. P. Linthorne, B. A. Kemble. - Proceeding I of the XVI ISBS Symp., 1998. Universitatsverlag Konstanz, Germany. - P. 356-359.

9. Liu Y. Biomechanical diagnosis and analysis of top Chinese high jumpers / Y. Liu, P. Danny, Y. Hong // Proceedings I of the XVI ISBS Symp., 1998. Universitatsverlag Konstanz, Germany. - P. 175.

10. Nicholson G. Biomechanical report for the high jump women's / Gareth Nicholson, Athanassios Bissas, Stéphane Merlino // Scientific report on the sixteen IAAF world championships in athletics. - London., 2017. -31 p.

11. Ritsdorf W. Biomechanical analysis of the high jump / W. Ritsdorf, A. Cornad // Scientific report on the second IAAF world championships in athletics. - Rome: International Athletic Foundation, 1988 - P. 1-50.

12. Tidow G. Model technique analysis sheets: The Flop High Jump / G. Tidow // New studies in athletics. 1993. - Vol. 8, № 1. - P. 31-44. 